\title{
Effect of packing type and storage temperature on microbial growth and quality of fresh-cut onions (Allium cepa cv. turbo)
}

\author{
Yeoung-Seuk Bae*, Hyun-Jin Choi, Jung-Soo Lee, Mehea Park, \\ Ji-Weon Choi, Ji-Gang Kim \\ Postharvest Research Division, National Institute of Horticultural and Herbal Science, Wanju 55365, Korea
}

\section{포장방법과 저장온도가 신선편이 양파의 품질 및 미생물 생장에 미치는 영향}

\author{
배영석*·최현진 · 이정수 · 박미희 · 최지원 · 김지강 \\ 국립원예특작과학원 저장유통과
}

\begin{abstract}
Inappropriate storage of fresh-cut onions may result in losses of good quality. To understand storage conditions for shelf-life and quality of fresh-cut onions, The effect of packing type and storage temperature on the quality of fresh-cut onions was evaluated. Onions stored at $0{ }^{\circ} \mathrm{C}$ for 2 months were peeled off after removing root and shoot parts. Each three peeled onions were packed in a polyethylene film $(\mathrm{PE}, 50 \mathrm{\mu m})$ or in a polyethylene/polypropylene film $(\mathrm{PE} / \mathrm{PP}, 100 \mu \mathrm{m})$ with vacuum treatment $(70 \mathrm{cmHg})$ and stored at different temperatures $\left(4\right.$, and $\left.10^{\circ} \mathrm{C}\right)$ for 21 days. The following analyses were examined to evaluate the quality of fresh-cut onions: microbial population, surface color, titratable acidity and $\mathrm{pH}$, respiration rate, and sensory quality. Fresh-cut onions stored at $4^{\circ} \mathrm{C}$ showed less aerobic and coliform bacterial population than those stored at $10^{\circ} \mathrm{C}$ during observation periods. Fungal populations of fresh-cut onions packed in PE film stored at $10^{\circ} \mathrm{C}$ increased significantly after 13 days. $E$. coli was not detected in all treatments during whole storage periods. Surface colors of fresh-cut onions were not affected by packing type and storage temperature, however, color difference $(\Delta E)$ of fresh-cut onions in $\mathrm{PE} / \mathrm{PP}$ film stored at $10^{\circ} \mathrm{C}$ was significantly higher than those of other treatments. Titratable acidity of fresh-cut onions was not affected by packing type and storage temperature. However, $\mathrm{pH}$ of fresh-cut onions packed in $\mathrm{PE}$ film stored at $10^{\circ} \mathrm{C}$ increased gradually over the whole storage period. Fresh-cut onions packed in $\mathrm{PE}$ film showed higher $\mathrm{CO}_{2}$ and less $\mathrm{O}_{2}$ concentrations at $10{ }^{\circ} \mathrm{C}$ than those at $4^{\circ} \mathrm{C}$. The sensory quality of fresh-cut onions was significantly affected by packing type and storage temperature after 13 days. Particularly, vacuum treatment in PE/PP film showed better sensory quality than that of PE film package at the same storage temperature. It was concluded that vacuum treatment and storage at $4^{\circ} \mathrm{C}$ could be effective to prolong the quality of fresh-cut onions up to 21 days.
\end{abstract}

Key words : fresh-cut, onion, packing type, storage temperature, microbial population, quality

\section{서 론}

신선편이 채소(Fresh-cut vegetables)는 채소류를 수확 후, 박피, 절단, 세척, 포장 등 일련의 공정을 거쳐 신선함과

*Corresponding author. E-mail : ysbae63@korea.kr Phone : 82-63-238-6510, Fax : 82-63-238-6505

Received 31 May 2016; Revised 8 August 2016; Accepted 9 August 2016.

Copyright (c) The Korean Society of Food Preservation. All rights reserved.
편리함을 부여한 농산물로 크게 조리가공용과 즉석섭취용 으로 구분하며(1-3), 소비자의 외식 확대, 소득수준 향상, 1 인 가구의 증가 등에 따른 국내 식문화 변화와 함께 편이 성, 경제성, 환경적 측면으로 볼 때 그 수요는 점점 증가할 것으로 예상된다(4). 신선편이 채소는 살아있는 생체 조직 으로 가공과정 중 발생할 수 있는 세포조직의 파괴와 원료 의 껍질 제거와 절단에 따른 생리적 및 생화학적 변화, 미생 물 증식에 따른 부패 등에 의해 품질은 빠르게 변할 수 있으며, 이러한 변화는 외관의 색상, 조직감, 향미 등의 손실 을 초래하여 선도유지기간 및 저장성이 짧아지게 된다 
$(2,4,5)$.

신선편이 채소의 품질 유지 및 저장성 향상을 위한 연구 는 가공 시 초기 미생물 또는 병원성 미생물의 밀도를 감소 시켜 저장성을 향상하고자 하는 가공방법 연구(6), 유통 중 품질변화를 억제하기 위한 가공 중 처리기술 개발(7), 가공처리 후 유통 단계에서 품질변화를 억제하기 위한 포장 방법 연구(8)등으로 크게 구별된다. 그러나 채소는 품목별 로 다른 생리특성을 가지고 있어 신선편이 채소의 품질유지 및 저장성 향상을 위해서는 품목별로 품질유지 및 저장성에 미치는 요인에 알맞은 관리기술 연구가 필요하다.

양파(Allium cepa L.)는 백합과에 속하는 작물로 독특한 향미특성을 가져 우리나라에서는 주로 조미채소로 사용하 고 있다. 국내 양파의 재배면적은 2014년 23,911 ha로 생산 량은 159 만 톤으로 전년보다 각각 $19.3 \%, 22.8 \%$ 증가하였 고, 1 인당 소비량도 2014 년 $31.2 \mathrm{~kg}$ 으로 매년 증가하고 있는 추세이다(9). 양파는 유황화합물(S-alk(en)yl cystein sulfoxides, thiosulfinates, allyl disulfide 등), flavonoid(quercetin, rutin), glutathione 등 기능성 물질을 많이 가지고 있고, 이들 화합 물은 항산화, 항고혈압, 항동맥경화, 항균작용 등과 같은 효과가 있는 것으로 보고되고 있다(10-13). 양파의 독특한 향미 성분은 S-methyl cysteine sulfoxide, S-1-propenyl cysteine sulfoxide, S-propyl cysteine sulfoxide 등의 유황화 합물에 의해 결정되며, 대표적인 향기 성분의 전구체는 S-1-propenyl cysteine sulfoxide로 전체 향기 성분 전구체 중 $85 \%$ 를 차지한다(14). 그러나 이들 향기 성분과 매운 맛은 소비를 위한 양파 준비과정에서 소비자의 코와 눈을 자극하여 소비자가 기피하는 과정 중 하나로, 이러한 문제 를 해결할 수 있는 방법 중 하나가 신선편이 양파를 사용하 는 것이다.

최근 국내 급식산업과 외식산업이 증가하면서 양파의 수요도 증가하고 있는데 신선편이 양파는 조리용 박피 통양 파, 샐러드용 절단양파, 다진 양파 등의 형태로 가공하여 유통되고 있다. 국내 산업현장의 신선편이 양파 공정은 먼 저 원재료에 묻어 있는 흙 등 이물질을 제거하고, 양파 상단 의 줄기 부위와 하단의 뿌리 부위를 잘라내어 껍질을 제거 한 후 $10^{\circ} \mathrm{C}$ 깨끗한 물로 1 차 애벌세척을 한다. 세척한 양파 는 초기 미생물 및 병원성 미생물의 오염을 줄이기 위해 차아염소산나트륨 용액(100 150 ppm)으로 표면살균하고, 양파에 잔존하는 염소 성분을 제거하기 위해 $10^{\circ} \mathrm{C}$ 깨끗한 물로 다시 세척을 한다. 세척한 양파는 건조 후 박피 통양파 또는 절단 양파로 준비하여 포장과정을 거친다. 신선편이 채소의 유통과정 중 포장방법과 저장온도는 품질유지 및 저장성에 미치는 중요한 요인으로 신선편이 양파의 경우 포장방법은 진공 포장과 밀봉포장이 주로 사용되고 있고, 저장온도는 $4^{\circ} \mathrm{C}$ 저장고 또는 $10^{\circ} \mathrm{C}$ 내외의 진열장에서 저장 유통되고 있다. 그러나 신선편이 양파는 유통과정 중에 미 생물 오염에 의한 부패, 이취 발생, 변색, 진공 풀림 현상
등의 원인으로 상품성을 상실하여 반품이 되는 경우가 종종 발생하고 있다. 산업현장에서는 신선편이 양파의 포장방법 과 저장온도에 따른 유통기간 동안 품질변화에 관한 자료는 매우 중요하다 하겠으나 관련 기초자료는 매우 미흡한 실정 이다.

따라서 본 연구는 조리용 신선편이 양파를 가공하는 산 업현장과 유통업체에서 할용 할 수 있는 기술정보를 제공하 고자 포장방법과 저장온도가 신선편이 양파 유통 중 품질유 지에 미치는 영향을 조사하였다.

\section{재료 및 방법}

\section{실험재료 및 신선편이 가공·포장}

본 실험에 사용한 양파(Allium cepa L.)는 2015년 6월에 경남 창녕에서 구입한 터보 품종으로 가공처리 전까지 $0^{\circ} \mathrm{C}$ 의 저장고에 보관하였다. 양파는 상처가 나지 않고 외관이 깨끗하고 개체 무게가 $250 \mathrm{~g}$ 내외의 균일한 양파를 선별하 여 사용하였다. 저장 양파는 표면에 묻어 있는 이물질을 없애고 상단의 잎 부분과 하단의 뿌리 부분을 절단하고 껍질을 벗겨 제거하였다. 신선편이 양파 가공은 산업현장 에서 사용하고 있는 방법을 준용하였다. 즉, 박피한 통양파 를 $10^{\circ} \mathrm{C}$ 깨끗한 물로 1 차 세척한 다음 차아염소산나트륨 용액 $\left(100 \mathrm{ppm}, 10^{\circ} \mathrm{C}\right)$ 에서 2 분간 살균소독 하였다. 살균한 양파는 $10^{\circ} \mathrm{C}$ 깨끗한 물로 헹구고 약 2 시간 동안 상온에서 두어 과다한 수분을 제거하였다. 신선편이 양파의 포장재 는 산업체에서 사용하고 있는 polyethylene 필름(PE, $50 \mu \mathrm{m}$, $30 \times 40 \mathrm{~cm})$ 과 polyethylene/polypropylene 필름 $(\mathrm{PE} / \mathrm{PP}$; 내부 $\mathrm{PE}$ 및 외부 $\mathrm{PP}, 100 \mu \mathrm{m}, 25 \times 35 \mathrm{~cm})$ 을 사용하였다. 신선편이 양파 3개를 $\mathrm{PE}$ 또는 $\mathrm{PE} / \mathrm{PP}$ 필름에 넣고, $\mathrm{PE}$ 필름은 밀봉하 였고, $\mathrm{PE} / \mathrm{PP}$ 필름은 $73 \mathrm{cmHg}$ 압력에서 진공 포장하였다. 포장한 신선편이 양파는 $4^{\circ} \mathrm{C}\left(\mathrm{PE}-4^{\circ} \mathrm{C}, \mathrm{PE} / \mathrm{PP}-4^{\circ} \mathrm{C}\right)$ 또는 $10^{\circ} \mathrm{C}$ $\left(\mathrm{PE}-10^{\circ} \mathrm{C}, \mathrm{PE} / \mathrm{PP}-10^{\circ} \mathrm{C}\right)$ 저장고에서 보관하면서 $1,5,9,13$, 17,21 일후 품질을 조사하였다.

\section{미생물 분석}

신선편이 양파를 가공한 후 $\mathrm{PE}$ 필름에 밀봉 포장하거나 $\mathrm{PE} / \mathrm{PP}$ 필름에 진공 포장한 후 $4^{\circ} \mathrm{C}$ 또는 $10^{\circ} \mathrm{C}$ 에 보관하면서 총 세균수, 대장균군수, 및 곰팡이수를 조사하였다. 미생물 분석은 멸균한 식칼을 이용하여 처리별 신선편이 양파 3 개 를 각각 4 등분하고 각각 $1 / 4$ 조각을 다시 잘게 썰어 혼합 시료를 만들고 그 중 $20 \mathrm{~g}$ 을 채취하여 filter bag(BACct)에 넣고 멸균수 $180 \mathrm{~mL}$ 를 추가하였다. 각각의 미생물 분석 시료는 균질기(Interscience Bag Mixer ${ }^{\circledR} 400$, Pro Scientific Co., Oxford, CT, USA)에서 2분간 균질화하였다. 균질화한 시료의 희석액은 필터를 통해 시험관(Falcon tube, $50 \mathrm{~mL}$ 용) 에 분주하고 10 배씩 단계적으로 희석한 후 적정 희석액 
$1 \mathrm{~mL}$ 를 Petrifilm(3M, Aerobic, E.coli/Coliform, Yeast/Mold count plates)에 각각 도말하였다. Aerobic 및 E.coli/Coliform count plates는 $35^{\circ} \mathrm{C}$ 에서 2 일간 배양하였고, Yeast/Mold count plates는 $25^{\circ} \mathrm{C}$ 에서 5 일간 배양하여 균수를 조사하였다.

\section{품질조사 측정 및 포장 내 기체조성}

신선편이 양파 저장 중 시료의 색도 측정은 표준백판 $\left(\mathrm{L}^{*}=97.3, \mathrm{a}^{*}=0.08, \mathrm{~b}^{*}=1.74\right)$ 으로 보정된 색차계(Chromameter CR-300, Minolta Co., Tokyo, Japan)을 사용하여 신선편이 양파를 1 겹 제거한 과육부위의 표면색을 무작위로 6 회 측 정하고 그 결과를 각각 $\mathrm{L}^{*}$ (명도), $\mathrm{a}^{*}$ (적색도), $\mathrm{b}^{*}$ (황색도) 값 으로 나타내었다. 또한 저장기간 중 변색된 색의 값은 저장 1 일째 값을 기준으로 색차는 $\Delta \mathrm{E}=\left(\Delta \mathrm{L}^{2}+\Delta \mathrm{a}^{2}+\Delta \mathrm{b}^{2}\right)^{0.5}$ 로 표시 하였다(15).

신선편이 양파의 산도 및 $\mathrm{pH}$ 조사는 신선편이 양파를 깨끗한 칼로 잘게 조각을 내고 4겹의 거즈로 쌓고 착즙기를 이용하여 약 $20 \mathrm{~mL}$ 의 즙액을 채취하였다. 채취한 즙액 2 $\mathrm{mL}$ 는 멸균수 $18 \mathrm{~mL}$ 에 희석하고 $\mathrm{pH}$ meter(TitroLine easy, Schott, Mainz, Germany)를 이용하여 $\mathrm{pH} 8.24$ 까지 도달하는 데 필요한 $0.1 \mathrm{~N} \mathrm{NaOH}$ 의 양을 측정하여 산도를 계산하였 다. $\mathrm{pH}$ 는 나머지 양파 즙액을 이용하여 측정하였다.

신선편이 양파의 저장기간 중 포장 내부의 기체조성 $\left(\mathrm{O}_{2}\right.$, $\mathrm{CO}_{2}$ )은 $\mathrm{PE}$ 필름에 밀봉 포장하여 $4^{\circ} \mathrm{C}$ 및 $10^{\circ} \mathrm{C}$ 저장한 처리 구만 조사하였다. 신선편이 양파를 포장한 $\mathrm{PE}$ 필름에 septum을 부착한 후 기체분석기(CheckMate 3, PBI Dansensor, Ringsted, Denmark)를 이용하여 측정하였다.

\section{관능평가}

신선편이 양파의 관능적 품질평가는 Das 등(16)과 같이 4명의 훈련된 평가원들이 시료 포장을 개봉한 즉시 이취를 평가하였으며, 이어 전체 외관 품질, 물러짐 및 변색 정도를 조사하였다. 이취, 물러짐 및 변색 발생 정도는 5 단계의 점수를 부여 $(0$, 없음; 1 , 약간; 2 , 보통; 3 , 심함; 4 , 매우 심함)하였으며, 점수 2 를 초과하는 것은 상품성이 없는 것 으로 간주하였다. 또한 전체 외관 품질도 5 단계의 점수를 부여(1, 매우 나쁨; 2 , 나쁨; 3 , 보통; 4 , 좋음; 5 , 매우 좋음)하 고 점수 3점을 상품성 한계로 간주하였다(17).

\section{통계분석}

모든 실험은 무작위 3 반복으로 수행하였으며, 그 결과는 $\mathrm{JMP} \mathrm{IN}^{\circledR}$ software(SAS Institute Inc.)를 이용하여 ANOVA 분석을 실시하고, Tukey-Kramer honestly significant difference ( $<<0.05)$ 로 처리구 및 조사시기별 유의성 검정을 실시하였다.

\section{결과 및 고찰}

미생물학적 특성

신선편이 양파를 $\mathrm{PE}$ 필름에 밀봉 포장 및 $\mathrm{PE} / \mathrm{PP}$ 필름에
진공 포장하여 $4^{\circ} \mathrm{C}$ 및 $10^{\circ} \mathrm{C}$ 에 저장하였을 때 총 세균수의 변화는 Fig. 1과 같다. 신선편이 양파를 PE 필름에 포장하여 $4{ }^{\circ} \mathrm{C}$ 에 저장 유통 시 총 세균수는 저장 1 일째에 $1.82 \pm 0.14$ $\log \mathrm{CFU} / \mathrm{g}$, 저장 21 일에 $5.81 \pm 0.42 \log \mathrm{CFU} / \mathrm{g}$ 로 증가하였으 며, $10^{\circ} \mathrm{C}$ 에 저장 유통하였을 때 총 세균수는 저장 1 일에 $2.81 \pm 0.37 \log \mathrm{CFU} / \mathrm{g}$ 에서 저장 21일에 $6.34 \pm 0.14 \log \mathrm{CFU} / \mathrm{g}$ 로 증가하여 $4^{\circ} \mathrm{C}$ 보다 높은 밀도를 나타내었다. 또한, 신선편 이 양파를 $\mathrm{PE} / \mathrm{PP}$ 에 진공 포장하여 $4{ }^{\circ} \mathrm{C}$ 에 저장했을 때 저장 1 일에 $2.45 \pm 0.38 \log \mathrm{CFU} / \mathrm{g}$ 에서 저장 21 일에 $5.96 \pm 0.62 \log$ $\mathrm{CFU} / \mathrm{g}$ 로 증가하였고, $10^{\circ} \mathrm{C}$ 에서는 저장 1 일에 $3.31 \pm 0.14 \mathrm{log}$ $\mathrm{CFU} / \mathrm{g}$ 에서 저장 21일에 7.92 $\pm 0.21 \log \mathrm{CFU} / \mathrm{g}$ 로 증가하여 총 세균의 밀도는 포장방법(PE 밀봉 포장 또는 $\mathrm{PE} / \mathrm{PP}$ 진공 포장)보다는 저장온도에 더 큰 영향을 받았다. 즉, 신선편이 양파는 $10^{\circ} \mathrm{C}$ 에서 보다 $4^{\circ} \mathrm{C}$ 에 저장 유통할 때 총 세균의 밀도를 낮게 유지할 수 있음을 알 수 있었다. Kim 등(18)의 연구에서는 신선편이 양파를 가공하였을 때 초기 총 균수는 $2.87 \log \mathrm{CFU} / \mathrm{g}$ 수준이었으며, 신선편이 양파를 $4^{\circ} \mathrm{C}$ 에 저장 했을 때 저장 10 일째에 $3.69 \log \mathrm{CFU} / \mathrm{g}, 10^{\circ} \mathrm{C}$ 에서는 저장 10 일째에 $6 \log \mathrm{CFU} / \mathrm{g}$ 수준으로 증가하여 본 연구도 이와 비슷한 경향을 나타내었다. 진공포장은 저장 초기 포장 내 산소 공급을 억제하여 신선편이 양파의 화학적 또는 생화학 적 변화 억제(19)하고 호기성 미생물의 증식을 억제할 것으 로 기대하였으나 본 연구에서는 진공 포장에 의한 세균의 증식 억제 효과는 낮았다.

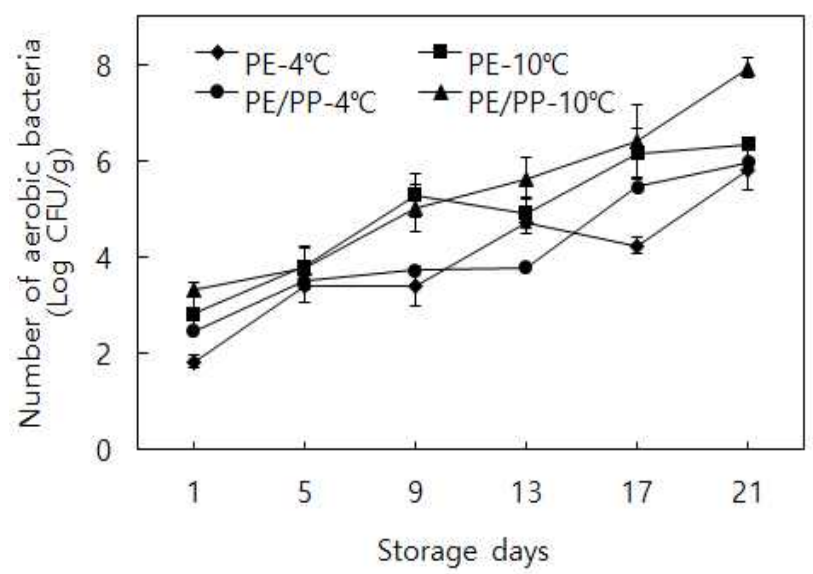

Fig. 1. Changes of total aerobic bacteria in fresh-cut onions packed in polyethylene (PE) film or polyethylene/polypropylene (PE/PP, inside; PE, outside; PP) film at $4^{\circ} \mathrm{C}(\boldsymbol{\nabla})$ and $10^{\circ} \mathrm{C}(\boldsymbol{\square}, \boldsymbol{\Delta})$ storages.

Fresh-cut onions in PE/PP film were vacuumed at the pressure of $73 \mathrm{cmHg}$ for 2 min. Vertical bars represent standard deviation.

대장균군은 신선편이 양파를 $10^{\circ} \mathrm{C}$ 에 저장 유통 시 저장 13 일부터 검출 $\left(\mathrm{Fig} .2, \mathrm{PE}-10^{\circ} \mathrm{C}\right.$ 및 $\mathrm{PE} / \mathrm{PP}-10^{\circ} \mathrm{C}$ )되었으며, 가 장 높은 밀도는 $\mathrm{PE}-4^{\circ} \mathrm{C}$ 처리구에서 저장 21 일에 $3.75 \mathrm{log}$ $\mathrm{CFU} / \mathrm{g}, \mathrm{PE}-10^{\circ} \mathrm{C}$ 에서는 $4.43 \log \mathrm{CFU} / \mathrm{g}, \mathrm{PE} / \mathrm{PP}-4^{\circ} \mathrm{C}$ 에서는 
$2.29 \log \mathrm{CFU} / \mathrm{g}$ 를, $\mathrm{PE} / \mathrm{PP}-10^{\circ} \mathrm{C}$ 에서는 저장 13 일에 $3.2 \mathrm{log}$ $\mathrm{CFU} / \mathrm{g}$ 을 나타내었다. 그러나 대장균 $(E . c o l i)$ 은 조사기간 중 검출(검출한계 $1 \log \mathrm{CFU} / \mathrm{g}$ )되지 않았으며, 이는 다른 연구자들이 보고 $(20,21)$ 한 바와 같이 신선편이 양파 가공 시 차아염소산나트륨의 사용에 따른 것으로 판단된다.

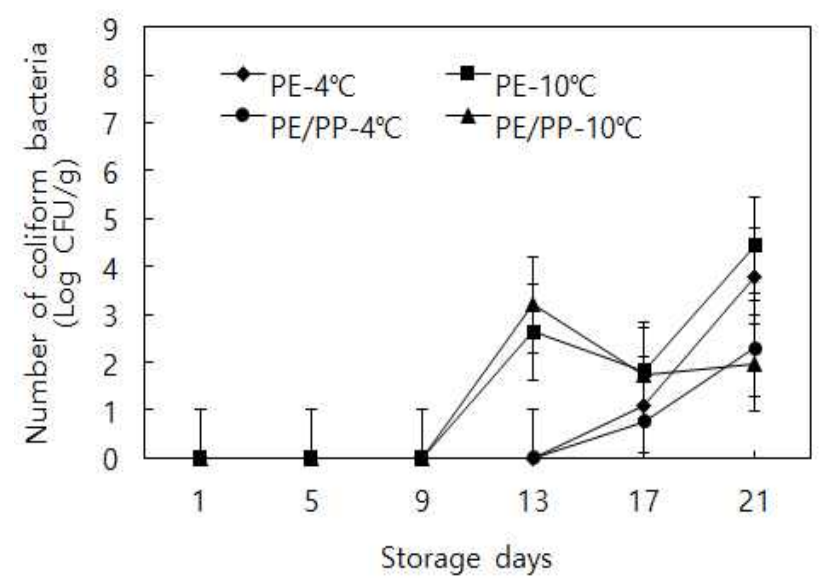

Fig. 2. Changes of coliform bacteria in fresh-cut onions packed in polyethylene (PE) film or polyethylene/polypropylene (PE/PP, inside; $\mathrm{PE}$, outside; PP) film at $4^{\circ} \mathrm{C}(\boldsymbol{\nabla}, \mathbf{O})$ and $10^{\circ} \mathrm{C}(\boldsymbol{\square}, \boldsymbol{\Delta})$ storages.

Fresh-cut onions in PE/PP film were vacuumed at the pressure of $73 \mathrm{cmHg}$ for 2 $\min$. Vertical bars represent standard deviation.

신선편이 양파 저장 중 곰팡이는 효모(yeast)를 포함한 전체 곰팡이를 조사한 결과, 저장 초기(1일)의 곰팡이 밀도 는 PE film에 밀봉 포장한 경우 각각 $1.17 \log \left(10^{\circ} \mathrm{C}\right.$ 저장 $)$, $1.76 \log \left(4^{\circ} \mathrm{C}\right.$ 저장 $)$ 로 $\mathrm{PE} / \mathrm{PP}$ film으로 진공 포장한 신선편이 양파의 곰팡이 밀도 $\left(4^{\circ} \mathrm{C}\right.$ 저장 시 $2.14 \log , 10^{\circ} \mathrm{C}$ 저장 시 $2.21 \mathrm{log}$ )보다 다소 낮았으나 5\%의 유의수준에서 유의적인 차이는 없었다(Fig. 3). 그러나 PE film에 밀봉 포장하여 $10^{\circ} \mathrm{C}$ 에 저장했을 때 저장 13 일부터 밀도가 급격히 증가 $(5.88 \mathrm{log})$ 하여 저장 21 일에는 $7.02 \log$ 를 보여 다른 처리에 비해 현저히 높은 밀도를 보였다( $\mathrm{p}<0.05)$. 이와 같은 결과는 신선편이 양파 유통 중에 발생하는 곰팡이는 호기성 곰팡이 로 저장 13 일 이후 포장 내 산소 농도의 감소와 함께 이산화 탄소의 농도가 증가(Fig. 5)하여 곰팡이의 생장단계가 영양
생장에서 생식생장으로 전환되어 포자가 형성하여 높은 밀도가 검출된 것으로 판단된다.

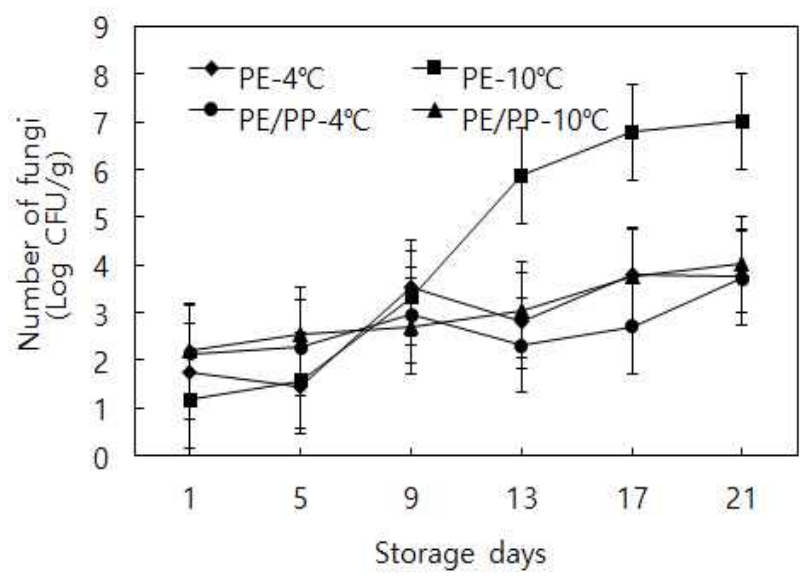

Fig. 3. Changes of total fungi in fresh-cut onions packed in polyethylene (PE) film or polyethylene/polypropylene (PE/PP, inside; $\mathrm{PE}$, outside; PP) film at $4^{\circ} \mathrm{C}$ and $10^{\circ} \mathrm{C}$

$\boldsymbol{\square}, \boldsymbol{\Delta})$ storages.

Fresh-cut onions in PE/PP film were vacuumed at the pressure of $73 \mathrm{cmHg}$ for 2 min. Vertical bars represent standard deviation.

\section{표면 색도}

신선편이 양파의 포장방법과 저장온도별 표면색의 변화 는 Fig. 4와 같다. 포장방법이나 저장온도는 신선편이 양파 의 색도 $\left(\mathrm{L}^{*}, \mathrm{a}^{*}, \mathrm{~b}^{*}\right)$ 변화에 미치는 영향은 없었으며, 다만 $\mathrm{PE} / \mathrm{PP}$ 에 진공 포장하여 $10^{\circ} \mathrm{C}$ 에서 저장했을 때 저장 5 일부 터 17 일까지 다른 처리구에 비해 현저히 높은 색차값 $(\Delta \mathrm{E})$ 을 나타내었다 $(\mathrm{p}<0.05)$.

\section{산도 및 $\mathrm{pH}$}

저장 기간 중 신선편이 양파의 생리대사 속도는 산도 및 $\mathrm{pH}$ 의 증감과 밀접한 관계가 있다고 알려져 있어(22), 신선편이 양파의 포장방법 및 저장온도에 따른 산도 및 $\mathrm{pH}$ 변화는 조사하였다(Table 1). 신선편이 양파의 산도는 $\mathrm{PE} / \mathrm{PP}-4^{\circ} \mathrm{C}$ 처리구를 제외한 모든 처리구에서 저장시간이 지나면서 다소 증가하였으며, $\mathrm{pH}$ 는 $\mathrm{PE}-4^{\circ} \mathrm{C}$ 및 $\mathrm{PE}-10^{\circ} \mathrm{C}$ 처 리구에서 저장시간이 지나면서 다소 낮아지는 경향이었다.

Table 1. Changes of acidity and $\mathrm{pH}$ in fresh-cut onions packed in polyethylene (PE) film or polyethylene/polypropylene (PE/PP) film at $4{ }^{\circ} \mathrm{C}$ and $10^{\circ} \mathrm{C}$ storages

\begin{tabular}{|c|c|c|c|c|c|c|c|c|c|c|c|c|c|}
\hline \multirow{2}{*}{ Packaging } & \multirow{2}{*}{$\begin{array}{l}\text { Storage temperature } \\
\left({ }^{\circ} \mathrm{C}\right)\end{array}$} & \multicolumn{6}{|c|}{ Acidity $(\%)$ for storage time } & \multicolumn{6}{|c|}{$\mathrm{pH}$ for storage time } \\
\hline & & 1 day & 5 days & 9 days & 13 days & 17 days & 21 days & 1 day & 5 days & 9 days & 13 days & 17 days & 21 days \\
\hline \multirow{2}{*}{ PE } & 4 & $0.175^{\mathrm{a22}}$ & $0.174^{\mathrm{a}}$ & $0.162^{\mathrm{a}}$ & $0.164^{b}$ & $0.178^{\mathrm{a}}$ & $0.192^{\mathrm{a}}$ & $5.65^{\mathrm{a}}$ & $5.66^{b}$ & $5.75^{b}$ & $5.77^{\mathrm{b}}$ & $5.55^{\mathrm{c}}$ & $5.58^{\mathrm{c}}$ \\
\hline & 10 & $0.166^{\mathrm{a}}$ & $0.167^{\mathrm{a}}$ & $0.171^{\mathrm{a}}$ & $0.168^{\mathrm{b}}$ & $0.175^{\mathrm{a}}$ & $0.183^{\mathrm{ab}}$ & $5.78^{\mathrm{a}}$ & $5.72^{\mathrm{b}}$ & $5.73^{\mathrm{b}}$ & $5.66^{\mathrm{b}}$ & $5.52^{\mathrm{c}}$ & $5.43^{\mathrm{c}}$ \\
\hline \multirow{2}{*}{$\mathrm{PE} / \mathrm{PP}^{1)}$} & 4 & $0.179^{\mathrm{a}}$ & $0.160^{\mathrm{a}}$ & $0.175^{\mathrm{a}}$ & $0.197^{\mathrm{a}}$ & $0.173^{\mathrm{a}}$ & $0.170^{b}$ & $5.73^{\mathrm{a}}$ & $5.73^{\mathrm{b}}$ & $5.75^{\mathrm{b}}$ & $5.74^{\mathrm{b}}$ & $5.78^{\mathrm{b}}$ & $5.86^{\mathrm{b}}$ \\
\hline & 10 & $0.154^{\mathrm{a}}$ & $0.162^{\mathrm{a}}$ & $0.155^{\mathrm{a}}$ & $0.159^{\mathrm{b}}$ & $0.162^{\mathrm{a}}$ & $0.161^{b c}$ & $5.67^{\mathrm{a}}$ & $5.95^{\mathrm{a}}$ & $6.07^{\mathrm{a}}$ & $6.22^{\mathrm{a}}$ & $6.33^{\mathrm{a}}$ & $6.34^{\mathrm{a}}$ \\
\hline
\end{tabular}

${ }^{1)}$ Fresh-cut onions in PE/PP films were vacuumed at the pressure of $73 \mathrm{cmHg}$ for $2 \mathrm{~min}$.

${ }^{2}$ Different superscript letters in a column indicate significant differences among samples at $\mathrm{p}<0.05$ (Tukey-Kramer honestly significant difference) 

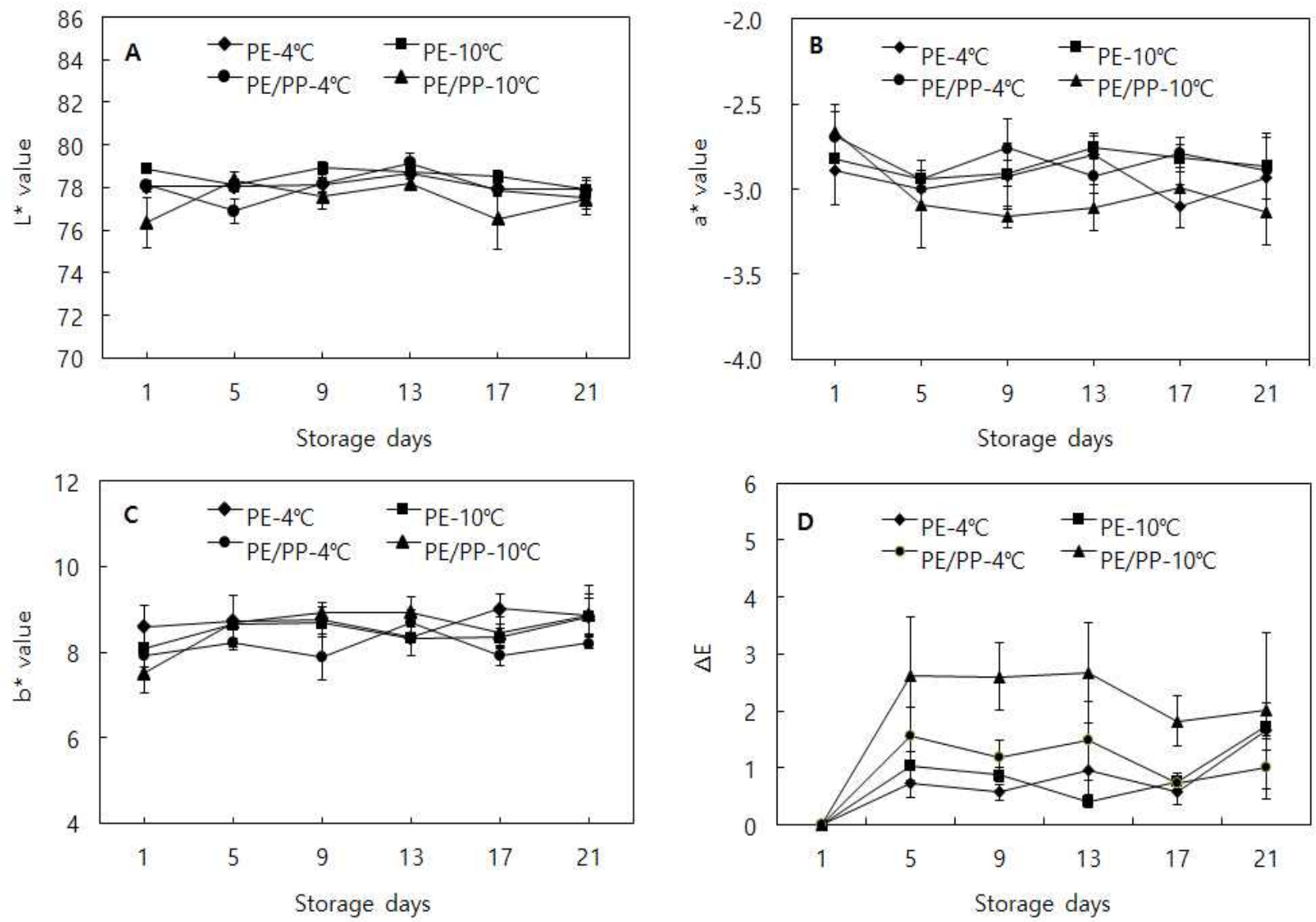

Fig. 4. Changes of color parameters $L^{*}(A), a^{*}(B), b^{*}(C), \Delta E$ (D) in fresh-cut onions packed in polyethylene (PE) film or polyethylene/polypropylene (PE/PP, inside; PE, outside; PP) film at $4^{\circ} \mathrm{C}(\boldsymbol{O})$ and $10^{\circ} \mathrm{C}(\boldsymbol{\square}, \boldsymbol{\Delta})$ storages.

Fresh-cut onions in PE/PP film were vacuumed at the pressure of $73 \mathrm{cmHg}$ for $2 \mathrm{~min}$. Vertical bars represent standard deviation.
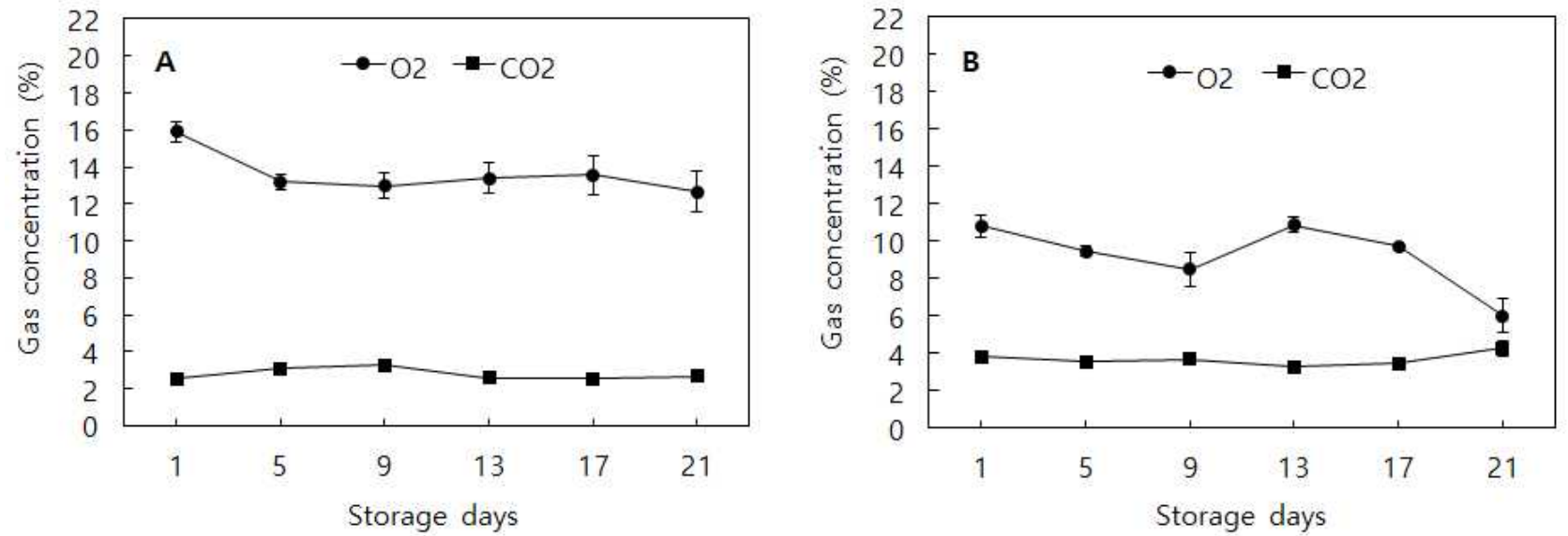

Fig. 5. Changes of $\mathrm{O}_{2}$ and $\mathrm{CO}_{2}$ concentrations inside the PE packages of fresh-cut onions at $4^{\circ} \mathrm{C}$ (A) and $10^{\circ} \mathrm{C}$ (B) storages. Vertical bars represent standard deviation.

이와는 반대로 $\mathrm{PE} / \mathrm{PP}-10^{\circ} \mathrm{C}$ 처리구는 시간이 지나면서 $\mathrm{pH}$ 가 증가하는 경향이었다. Berno 등(22)은 신선편이 양파를 1 $5^{\circ} \mathrm{C}$ 에 저장했을 때 생리대사가 활발해지면서 산도는 증가
하고 $\mathrm{pH}$ 는 감소하였다고 보고하였는데, 본 연구에서 $\mathrm{PE}$ 필름에 신선편이 양파를 밀봉하여 저장했을 때 산도 및 $\mathrm{pH}$ 는 이와 유사한 경향을 보였다. 


\section{포장 내 기체조성}

신선편이 양파를 $\mathrm{PE}$ 필름에 밀봉 포장하여 저장하였을 때 포장 내 기체조성 $\left(\mathrm{O}_{2}\right.$ 및 $\left.\mathrm{CO}_{2}\right)$ 변화는 Fig. 5와 같다. 신선편이 양파의 저장 온도는 포장 내 기체조성에 큰 영향 을 미쳤으며, $4^{\circ} \mathrm{C}$ 보다 $10^{\circ} \mathrm{C}$ 에 저장 했을 때 높은 $\mathrm{CO}_{2}$ 농도 및 낮은 $\mathrm{O}_{2}$ 농도를 나타내었다. $\mathrm{O}_{2}$ 농도는 $4{ }^{\circ} \mathrm{C}$ 에서 저장 초기 $15.89 \%$ 였으나 저장 기간이 지나면서 감소하여 저장 21 일째에는 $12.67 \%$ 로 나타내었다. $10^{\circ} \mathrm{C}$ 에서는 저장 초기 $10.83 \%$ 로 저장 9일째(12.97\%)까지 감소하다가 저장 13 일 째 $10.87 \%$ 로 다소 증가하였으나 저장 21 일째에 $6 \%$ 로 크게 감소하였다. $\mathrm{CO}_{2}$ 농도는 $4^{\circ} \mathrm{C}$ 에서 저장 초기 $2.53 \%$ 를 나타 내었으며, 저장 9 일(3.3\%)까지 증가하다가 저장 21 일째에 $2.7 \%$ 로 저장 초기의 농도와 유사하였다. $10^{\circ} \mathrm{C}$ 에서는 저장 초기 $3.83 \%$ 로 저장 13 일(3.27\%)까지 다소 감소하다가 저장 21 일에는 $4.27 \%$ 로 증가하였다. Berno 등(22)의 연구에서 신선편이 양파를 $15^{\circ} \mathrm{C}$ 에 저장했을 때 $0{ }^{\circ} \mathrm{C}$ 에 저장했을 때 보다 호흡률이 8 배 높았고, 더욱이 저온에 저장했을 때 저장 1 일째 평균 호흡률이 $12 \%$ 까지 감소하였으며, 저장 온도가 높을수록 신선편이 양파의 생리대사가 촉진되어 품질을
저하시켰다. 본 연구에서도 $4^{\circ} \mathrm{C}$ 에 저장했을 때보다 $10^{\circ} \mathrm{C}$ 에 저장했을 때 기체조성 변화가 심하였으며, $\mathrm{PE}$ 필름에 밀봉 하여 $10^{\circ} \mathrm{C}$ 에 저장한 신선편이 양파의 외관 품질이 가장 낮게 평가되었다(Fig. 6A).

\section{관능적 품질}

신선편이 양파를 $\mathrm{PE}$ 필름에 밀봉 포장하거나 $\mathrm{PE/PP}$ 필름 에 진공 포장하여 $4^{\circ} \mathrm{C}$ 및 $10^{\circ} \mathrm{C}$ 에 저장 유통 시 외관, 이취, 변색, 및 물러짐 정도는 Fig. 6과 같다. 신선편이 양파는 저장기간이 경과됨에 따라 외관 품질은 모든 처리구에서 점차 낮게 평가되었는데, 특히 저장 13 일 이후부터는 신선 편이 양파의 포장 방법 및 유통 온도에 따라 현저한 차이를 나타내었다 $(\mathrm{p}<0.05)$. 외관 품질의 한계를 3점으로 보았을 때 $\mathrm{PE}-4^{\circ} \mathrm{C}$ 에서는 17 일까지, $\mathrm{PE}-10^{\circ} \mathrm{C}$ 및 $\mathrm{PE} / \mathrm{PP}-10^{\circ} \mathrm{C}$ 에서는 9 일까지, $\mathrm{PE} / \mathrm{PP}-4^{\circ} \mathrm{C}$ 에서는 21 일까지 한계 값 이하로 평가 되었다. 이취 발생은 신선편이 양파의 유통 온도에 따라 차이가 있었는데, $4^{\circ} \mathrm{C}$ 에서보다 $10^{\circ} \mathrm{C}$ 에 저장 유통 시 저장 9일 이후 이취 발생 정도가 높게 나타났다. 이취 발생 한계 값 2 점을 기준으로 하였을 때 $\mathrm{PE}-10^{\circ} \mathrm{C}$ 에서는 17 일까지,
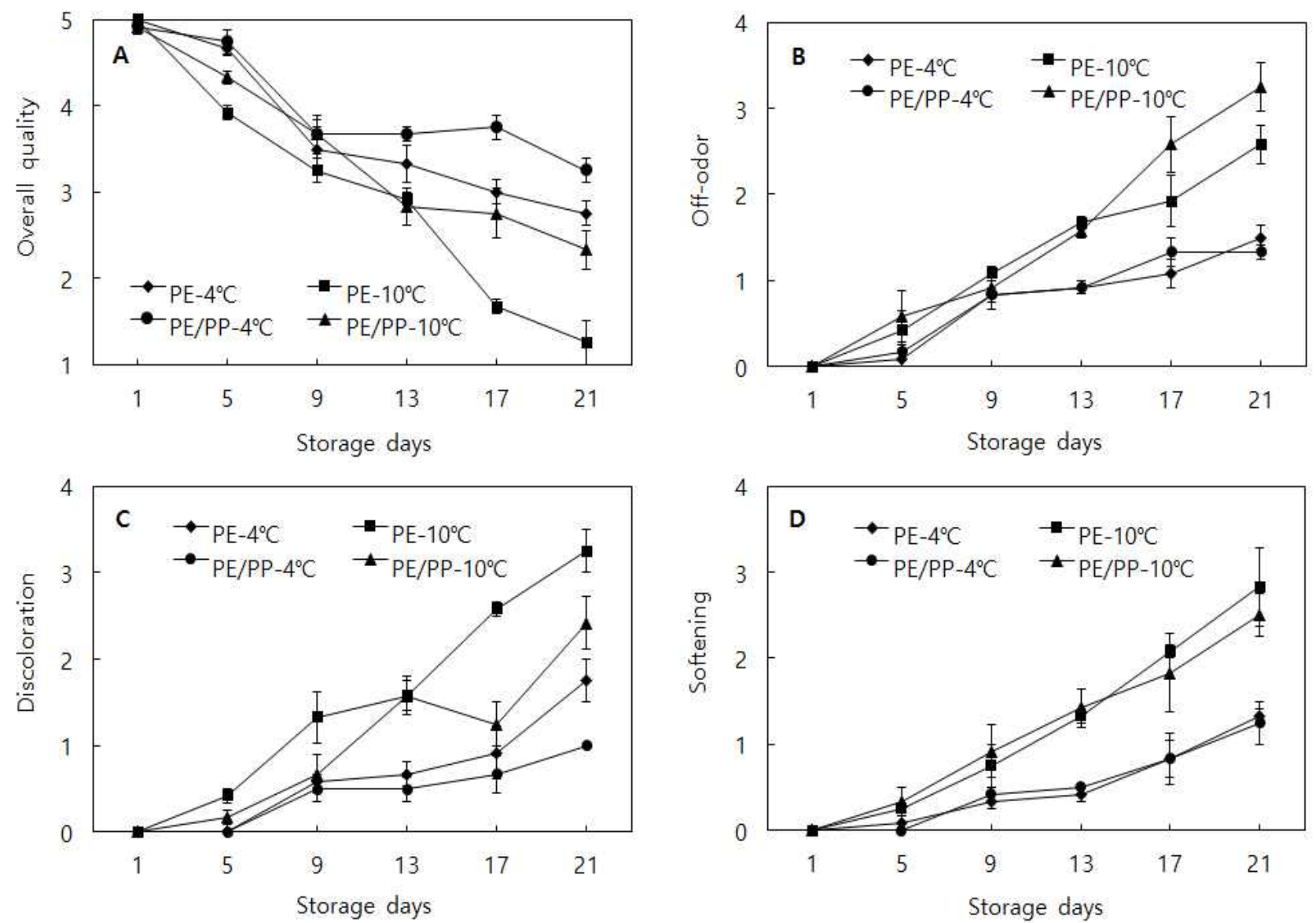

Fig. 6. Changes of sensory properties including appearance (A), off-odor (B), discoloration (C), and softening (D) of fresh-cut onions packed in polyethylene (PE) film or polyethylene/polypropylene (PE/PP, inside; PE, outside; PP) film at $4^{\circ} \mathrm{C}\left(\boldsymbol{\bullet}\right.$, and $10^{\circ} \mathrm{C}(\boldsymbol{\square}, \boldsymbol{\Delta})$ storages. Fresh-cut onions in $\mathrm{PE} / \mathrm{PP}$ film were vacuumed at the pressure of $73 \mathrm{cmHg}$ for 2 min. Vertical bars represent standard deviation. 
$\mathrm{PE} / \mathrm{PP}-10^{\circ} \mathrm{C}$ 에서는 13 일까지 2점 이하로 평가되었으며, $\mathrm{PE}-4^{\circ} \mathrm{C}$ 및 $\mathrm{PE} / \mathrm{PP}-4^{\circ} \mathrm{C}$ 에서는 저장 21 일까지 각각 1.5 및 1.3 점으로 평가되었다. 신선편이 양파의 변색 정도를 조사한 결과, 신선편이 양파의 변색은 유통 온도에 따라 큰 차이를 보였으며, 저장 5 일 이후부터 $4^{\circ} \mathrm{C}$ 에서보다 $10^{\circ} \mathrm{C}$ 에서 높게 평가되었다. 처리별 신선편이 양파의 변색 정도를 살펴보 면, $\mathrm{PE}-10^{\circ} \mathrm{C}$ 에서는 13 일 이후부터, $\mathrm{PE} / \mathrm{PP}-10^{\circ} \mathrm{C}$ 에서는 17 일 이후부터 한계 기준 값 2 점보다 높게 평가되었고, $\mathrm{PE}-4^{\circ} \mathrm{C}$ 및 $\mathrm{PE} / \mathrm{PP}-4^{\circ} \mathrm{C}$ 에서는 저장 21 일에 각각 1.3 및 1.2 점으로 평가되었다. 신선편이 양파의 저장 온도는 관능적 품질에 큰 영향을 주었으며, 동일한 저장 온도에서는 진공 포장한 신선편이 양파의 품질이 더 양호하였다. 본 연구 결과로 볼 때 신선편이 양파의 관능적 품질평가 중 가장 중요한 평가 항목은 외관 품질로 판단되었으며, 외관 품질은 실제 구매자나 소비자가 상품의 구매 의사를 결정할 때 큰 영향 을 주는 것으로 알려져 있다(23). 본 연구를 종합해 볼 때 신선편이 양파를 $\mathrm{PE} / \mathrm{PP}$ 필름에 진공 포장하고 $4{ }^{\circ} \mathrm{C}$ 에 저장 유통하는 것이 유통기한 연장 및 품질유지에 가장 효과적인 것으로 판단된다.

\section{요 약}

본 연구는 신선편이 양파의 포장방법 및 저장온도가 신 선편이 양파의 선도유지 및 품질에 미치는 영향을 알아보기 위해 저온 저장 중인 양파를 뿌리 및 줄기 부분을 절단하고 껍질을 제거하는 등 최소로 가공한 양파를 준비하였다. 최 소가공 한 신선편이 양파는 polyethylene(PE, $50 \mu \mathrm{m})$ 필름에 밀봉 포장하거나 polyethylene/polypropylene(PE/PP, $100 \mu$ $\mathrm{m})$ 필름에 진공 포장하고, $4^{\circ} \mathrm{C}$ 및 $10^{\circ} \mathrm{C}$ 에 저장하면서 21 일 동안 미생물 분석, 색도, 산도, $\mathrm{pH}$, 포장 내 기체변화, 관능적 품질을 조사하였다. 미생물 분석 결과 총 세균 및 대장균군 의 밀도는 포장방법보다는 신선편이 양파의 저장온도에 큰 영향을 받았으며, $10^{\circ} \mathrm{C}$ 보다는 $4^{\circ} \mathrm{C}$ 에 저장했을 때 세균의 밀도가 낮았다. 곰팡이는 $\mathrm{PE}$ 필름에 밀봉 포장하여 $10^{\circ} \mathrm{C}$ 에 저장했을 때 저장 13 일부터 다른 처리구에 비해 현저히 높은 밀도를 보였다. 그러나 대장균은 모든 처리구에서 조 사기간 동안 검출되지 않았다. 신선편이 양파의 표면 색도 값 $\left(\mathrm{L}^{*}, \mathrm{a}^{*}, \mathrm{~b}^{*}\right)$ 은 포장방법이나 저장온도에 따른 차이는 없었 으며, 다만 $\mathrm{PE} / \mathrm{PP}$ 에 진공 포장하여 $10^{\circ} \mathrm{C}$ 에 저장 했을 때 저장 5일부터 17 일까지 다른 처리구보다 현저히 높은 색차 값 $(\Delta \mathrm{E})$ 을 나타내었다 $(\mathrm{p}<0.05)$. 신선편이 양파의 산도는 포 장방법 및 저장온도에 따른 영향은 없었으며, $\mathrm{pH}$ 는 $\mathrm{PE} / \mathrm{PP}$ 필름에 진공 포장하여 $10^{\circ} \mathrm{C}$ 에 저장했을 때 저장시간이 지나 면서 점차 증가하는 경향이었다. $\mathrm{PE}$ 필름에 신선편이 양파 를 밀봉하고 포장 내 기체조성 변화를 조사한 결과 저장온 도 간에 현저한 차이를 나타내었으며, $4^{\circ} \mathrm{C}$ 에서 보다 $10^{\circ} \mathrm{C}$ 에
서 높은 $\mathrm{CO}_{2}$ 농도와 낮은 $\mathrm{O}_{2}$ 농도를 나타내었다 $(\mathrm{p}<0.05)$. 신선편이 양파의 외관 품질은 저장시간이 지나면서 점차 낮게 평가되었으며, 특히 저장 13 일 이후부터는 포장방법 및 저장온도에 따라 현저한 차이를 보였다 $(\mathrm{p}<0.05)$. 신선편 이 양파의 관능적 품질은 저장온도에 보다 큰 영향을 받았 으며, 동일한 저장 온도에서는 $\mathrm{PE}$ 필름에 밀봉한 양파보다 는 $\mathrm{PE} / \mathrm{PP}$ 필름에 진공 포장한 신선편이 양파의 품질이 더 양호하였다. 결과를 종합해보면 신선편이 양파를 $\mathrm{PE} / \mathrm{PP}$ 필름에 진공 포장하고 $4^{\circ} \mathrm{C}$ 에 저장 유통하는 것이 유통기한 연장 및 품질유지에 가장 효과적인 것으로 판단된다.

\section{감사의 글}

이 논문은 농촌진흥청 연구사업(세부과제번호: PJ01050204)의 지원에 의해 이루어졌으며, 이에 감사드립 니다.

\section{References}

1. Alzamora SM, Tapia MS, Lopez-Malo A (2000) Minimally processed fruits and vegetables : fundamental aspects and applications. Aspen Publishers Inc., Gaitjerburg, MD, USA, p 1-62

2. Lamikanra O (2002) Fresh-cut fruits and vegetables : science, technology, and markets. CRC Press, Boca Raton, FL, USA, p 1-43

3. Lund DB (1989) Food processing from art to engineering. Food Technol, 43, 242-247

4. Kim DM (1999) Extension of freshness of minimally processed fruits and vegetables. Korean J Hort Sci Technol, 17, 790-795

5. Lee HO, Kim JY, Yoon DH, Cha HS, Kim GH, Kim BS (2009) Microbial contamination in a fresh-cut onion processing facility. Korean J Food Preserv, 16, 567-572

6. Kim JG, Luo Y, Lim CI (2007) Effect of ozonated water and chlorine water wash on the quality and microbial de-contamination of fresh-cut carrot shreds. Korean J Food Preserv, 14, 54-60

7. Kim KM (2008) Color changes in fresh-cut fruit and vegetables and its pretreatment processing. J Kor Soc Packaging Sci Technol, 14, 23-29

8. Perez-Gregorio MR, Garcia-Falcon MS, Simal-Gandara J (2011) Flavonoids changes in fresh-cut onions during storage in different packing systems. Food Chemistry, 124, 652-658 
9. Ministry of Agriculture, Food and Rural Affairs (2015) Agriculture, Food and Rural Affairs Statistics Yearbook. Sejong, Korea, p 308-311

10. Hovius MHY, Goldman IL (2005) Flavor precursor [S-alk(en)yl-L-cysteine sulfoxide] concentration and composition in onion plant organs and predictability of field white rot reaction of onions. J Amer Soc Hort Sci, 130, 196-202

11. Corzo-Martinez M, Corzo N, Villamiel M (2007) Biological properties of onions and garlic. Trends Food Sci Technol, 18, 609-625

12. Yang YR, Park YK (2011) Black onions manufactured via the browning reaction and antioxidant effects of their water extracts. Korean J Food Preserv, 18, 310-318

13. Shim SM, Yi HL, Kim YK (2011) Bioaccessibility of flavonoids and total phenolic content in onions and its relationship with antioxidant activity. Int $\mathrm{J}$ Food Sci Nutr, $62,835-838$

14. Wang H, Li JM, Wang ZF, Zhang X, Ni YY (2007) Modified method for rapid quantitation of S-alk(en)yl-L-cysteine sulfoxide in yellow onions (Allium cepa L.). J Agric Food Chem, 55, 5429-5435

15. Sun SH, Kim SJ, Kim GC, Kim HR, Yoon KS (2011) Changes in quality characteristics of fresh-cut produce during refrigerated storage. Korean J Food Sci Technol, 43, 495-503

16. Das BK, Kim JG (2010) Microbial quality and safety of fresh-cut broccoli with different sanitizers and contact times. J Microbiol Biotechnol, 20, 363-369
17. Kim JG, Choi JW, Cho MA (2014) Quality changes of fresh-cut winter squash treated with different postharvest ripening periods and packaging methods. Korean J Food Preserv, 21, 17-24

18. Kim SJ, Sun SH, Kim GC, Kim HR, Yoon KS (2011) Quality changes of fresh-cut leafy and condiment vegetables during refrigerated storage. J Korean Soc Food Sci Nutr, 40, 1141-1149

19. Denoya GI, Vaudagna SR, Polenta G (2015) Effect of high pressure processing and vacuum packing on the preservation of fresh-cut peaches. LWT-Food Sci and Technol, 62, 801-806

20. Lee KH, Lim HK (2008) A study on the shelf-life extension of minimally processed carrot. J Food Hyg Safety, 23, 330-337

21. Lee KH, Kim DH (2009) A study on the shelf-life extension of fresh-cut onion (Allium cepa L.). J Food Hyg Safety, 24, 324-331

22. Berno ND, Tezotto-Uliana JV, Santos Dias CT, Kluge RA (2014) Storage temperature and type of cut affect the biochemical and physiological characteristics of fresh-cut purple onions. Postharvest Biol and Technol, 93, 91-96

23. Hong SI, Jo MN, Kim DM (2000) Quality attributes of fresh-cut green onion as affected by rinsing and packaging. Korean J Food Sci Technol, 32, 659-667 